\title{
Diş hekimliği fakültelerinde kullanılan farklı diş ünitlerinin su ünitlerinin su sistemlerinin geri akım kontaminasyonu açısından değerlendirilmesi
}

\author{
Hasan Önder Gümüş ${ }^{1}$, Osman Abdurrahman Etöz², Türker Yücesoy², \\ Erdem Kılıç2 ${ }^{2}$ Özgür $\mathrm{Er}^{3}$, Alper Alkan ${ }^{2}$
}

Basvuru Tarihi: 22 Ekim 2013 Yayına Kabul Tarihi: 28 Ekim 2013

Diş koltuk sistemleri, bir yüzyılı aşkın bir süredir diş hekimliği pratiğinin en önemli unsurları arasında yer almaktadır. Diş koltuk sistemlerinin temel işlevi dental işlem sırasında hastayı desteklerken, hekimin de rahat bir şekilde ağız içinde çalışmasını kolaylaştırmaktır. Illerleyen süreçte bu sistemler, dental işlemleri kolaylaştıııcı ve hızlandırıcı birçok aygıtla desteklenir hale gelmiştir (Montebugloni ve ark 2005, Stanley 1971). Bununla birlikte, modern bir diş koltuk sistemi yani diş üniti (DÜ), beraberinde hava-su spreyi, elektrikli ve/veya pnömatik döner aletler ve bu aletlerin oluşturduğu yüksek ısının önlenmesi amacıyla ileri teknoloji su ve su tahliye sistemleri ile beraber sunulmaktadır. Bu su sistemleri ünitlerin ayrımaz bir parçası halini almakla beraber rutin diş tedavileri sırasında diş ve çevre dokuların zarar görmesini engellemek amacıyla kullanılmaktadır (Mills 2000 ,Stanley 1971). Aynı zamanda bu su sistemleri, hastalar tarafından çalkalama ve temizleme işlemleri sırasında da kullanılmaktadır. Tüm bu su sistemleri karmaşık bir ağ ile diş koltuk sistemlerine entegre edilmiştir (Montebugloni ve ark 2005,Stanley 1971).

Dişhekimliği klinik uygulamalarında ağız içerisinde birçok turlu döner alet kullanılmakla beraber, özellikle restoratif dişhekimliği uygulamalarında yalıım önem arz etmektedir. Yapılacak restorasyonlar sırasında, hem ortamın kan ve tükürük ile kontaminasyonunu engellemek hem de döner aletlerin ortaya çıkardığı aşırı sıcaklıktan canlı diş dokusunu korumak amaciyla, diş ünitlerine (DÜ) özel su sistemleri entegre edilmekte, bu sayede soğutma ve artıkların uzaklaştıııması işlemleri yapılmaktadır. Bu su sistemleri, DÜ bünyesinde çalışan tüm turla dönen aletleri, kreşuvar ve hasta ağız çalkalama suyunu desteklemektedir. Bununla birlikte kullanılan artık suyun tahliyesi de ünitlere bağlı tükürük emicilerle sağlanmaktadır. DÜ'ye bağlı tüm bu su
The evaluation of escape-back avoiding system connected to water system of different dental units in dentistry faculties

Background: The purpose of the study is to search the efficiency of escape-back avoiding systems connected to dental units for a long time period and the determination of cross infection risks because of escapeback systems using in different branches.

Methods: Study groups are planned among between three different branches of dentistry. The difference between materials which are obtained from these three different study groups have been evaluated microbiologically in terms of the presence of bacteria.

Results: However various colonies of bacteria were isolated for all the groups, it has been resulted that most of the reproductive microorganisms in study groups were also isolated from environment and oral flora.

Conclusion: It has been concluded that providing contamination avoiding systems for dental units is extremely important and however dental unit systems must have been controlled frequently and revaluated for the necessity of renewal.

\section{KEY WORDS}

Dental unit escape-back systems, contamination, cross infection

\footnotetext{
${ }^{1}$ Erciyes Üniversitesi Diş Hekimliği Fakültesi, Protetik Diş Tedavisi Anabilim Dalı, Kayseri

${ }^{2}$ Erciyes Üniversitesi Diş Hekimliği Fakültesi, Ağız, Diş ve Çene Cerrahisi Anabilim Dalı, Kayseri

3 Erciyes Üniversitesi Diş Hekimliği Fakültesi, Endodonti Anabilim Dalı, Kayseri
} 
sistemi elemanları, potansiyel kontaminasyon ve çapraz enfeksiyon kaynağı teşkil etmektedir.

Uygun sterilizasyon yöntemleri kullanılmasına rağmen diş ünitleri bir enfeksiyon kaynağı olabilmektedir. Bu amaçla farklı diş ünitlerindeki su sistemlerinde kontamine sıvıların tekrar ünit içerisine dönüşünü engelleyen geri kaçışı engelleyici sistemler yerleştirilmesine rağmen etkinliğinin zaman içerisinde ortadan kalktığına dair çalışmalar mevcuttur. Bu projenin hayata geçirilmesiyle literatürde ilk defa modern dental ünit sistemlerinde bulunan geri kaçış engelleyici sistemlerin uzun dönem etkinliğini değerlendirilmiş olup muhtemel sorunların teknik olarak çözümüne önemli bir katkı sağlayacağı düşünülmektedir.

$\mathrm{Bu}$ çalışmanın amacı; farklı diş koltuk sistemlerine bağlı geri-kaçış engelleyici sistemlerin etkinliğinin uzun dönem araştırılması ve farklı branşlara göre gerikaçış sonucu ortaya çıkabilecek çapraz enfeksiyon riskinin belirlenmesidir.

\section{GEREÇ ve YÖNTEM}

Mevcut çalışmada iki ayrı çalışma grubu ve bir kontrol grubunun oluşturulması planlanmıştır. Kontrol grubundaki diş ünit sistemlerinin bir kısmının, hizmete açılmak üzere bulunan Erciyes Üniversitesi Ağız ve Çene Cerrahisi Hastanesinde bulunacak olması ve ağız ve çene cerrahisi uygulamalarının diş ünit su sistemlerinden bağımsız olarak uygulanmasıyla ideal bir kontrol grubunun oluşturulması planlanmaktadır. Grup 1 olarak belirtilen bu kontrol grubuyla aynı ünitler olup, aeratörleri oldukça yoğun bir biçimde kullanılan ünitler olması sebebiyle seçilen Restoratif Diş Hekimliği'ndeki ünitler Grup 2 olarak belirlenmiştir. Ünit ve aeratör kullanımının benzer şekilde yoğun olduğu Protetik Diş Tedavisi Anabilim Dalı'ndaki ünitler de Grup 3 olarak belirtilmiştir (Tablo 1). Bu farklı üç gruptan elde edilecek materyaller bakteri varlığı açısından değerlendirilerek gruplar arasındaki farklılık incelenecektir.

\section{Tablo 1.}

\section{Çalışma grupları}

Grup 1. Ağız,Diş ve Çene Cerrahisi Hastanesi lokal ameliyathane ve kliniğinde kullanılması düşünülen, ancak entegre su sistemleri daha önce hiç kullanılmamış diş ünitlerine bağlı mikromotorlardan çıkan suyun belli aralıklarda toplanması planlanan grup (Kontrol Grubu).

Grup 2. Kontrol grubu ile aynı diş ünitleri olup, Restoratif Diş Hekimliği'nde kullanılan diş ünitlerine bağlı aeratörlerden çıkan suyun belli aralıklarla toplanması planlanan grup.

Grup 3. Grup 2'deki işlemin Protetik Diş Tedavisi ve Restoratif Diş Hekimliği Anabilim Dalları'nda hali hazırda kullanılan diş ünitlerine uygulanması planlanan grup.
Çalışma için entegre geri-kaçış engelleyici sisteme sahip hiç kullanılmamış diş ünitlerine ihtiyaç olmuştur. Zira kullanılmış diş ünitlerinde bu çalışmada sınanması amaçlanan geri-kaçış engelleyici sistemlerin bulunmamasından dolayı hiç kullanımamış ve bu sisteme sahip diş ünitlerinin kullanıması gerekmektedir.

Mikrobiyolojik açıdan değerlendirmelerin yapılabilmesi için diş ünitlerinden belirli aralıklarla elde edilen sıvıların analiz edilmesi için tekli membran filtrasyon sistemi kullanılmıştır. Elde edilen örneklerden Gram (-) ve Gram (+) bakterilerin muhtemel varlığının tespit edilmesi için tanımlama kiti kullanılmış olup, bakteri üremesinin kontrol edilmesi için besi yeri olarak Columbia agar kullanılmıştır.

\section{BULGULAR}

Çalışmamız sonucunda çarpıcı sonuçların elde edildiği düşünülmektedir. Mikrobiyoloji Anabilim Dalı'nda yapılan mikrobiyolojik değerlendirmeler sonucunda 3 grupta da birçok bakterinin izole edildiği görülmekle birlikte üreyen mikroorganizmaların çoğunun çevreden ve ağız florasından sıklıkla izole edilen bakteriler olduğu görülmektedir (Tablo 2). Bu mikroorganizmaların birçoğu normal bireylerde basit dental girişimler sonrasında enfeksiyon oluşturması açısından düşük riskli olmakla beraber, bağışıklık sistemi baskılanmış hastalarda ciddi enfeksiyonlara neden olabilirler.

Tablo 2.

\section{Örneklerden elde edilen bakterilerin oranı}

\begin{tabular}{|llll|}
\hline Elde edilen bakteriler & $\begin{array}{l}\text { Kontrol } \\
\text { grubu }\end{array}$ & $\begin{array}{l}\mathbf{1 .} \\
\text { Deney } \\
\text { grubu }\end{array}$ & $\begin{array}{l}2 . \\
\text { Deney } \\
\text { grubu }\end{array}$ \\
\hline Bacillus Spp. & ++ & + & - \\
\hline Brevandimonas Dimunuta & ++ & - & - \\
\hline Kingella Kingae & + & - & - \\
\hline Achromobacter Spp & + & ++ & ++ \\
\hline Alcaligenes Faecalis & + & - & - \\
\hline Cupriavidus Pauculus & + & - & - \\
\hline Gram Negatif Non & - & + & ++ \\
\hline Fermantatif Basil & - & + & - \\
\hline Moraxella Spp. & - & + & - \\
\hline Ralstania Pikettii & - & + & + \\
\hline Ps Spp & - & - & +++ \\
\hline Delftia Acidovorans & - & - & \\
\hline
\end{tabular}




\section{TARTIŞMA}

Diş ünitlerine bağlı su sistemlerinin birçok hasta tarafından kullanılı̆̆ı göz önüne alındığında uygun olmayan koşullarda toplum sağlığını tehdit eden ciddi bir çapraz enfeksiyon kaynağı olarak karşımıza çıkabilmektedir (Stanley 1971). Bu durumun önlenmesi amacıyla yeni nesil diş ünitleri birçok yenilik içerse de bu riskin tam olarak önlenmesi halen netlik kazanmamıştır. 1960'lı yılların bașında diş ünitlerine bağı su sistemlerinde yüksek oranda bakteri üremesini bildiren ilk çalışmalar yayınlanmıştır. (Petti ve Tarsitani 2006,Williams ve ark 1993). Bunu takiben 1990'lı yılların başında diş ünitlerinin su sisteminden çıkan suyun mililitresinde 106'ya varan bakteri kolonileri tespit edilmiștir (O'Donnell ve ark 2006). Ancak bu bakteri oranının çoğunluğunun bu su sistemlerinin kaynağında bulunan düşük seviyedeki bakteri sayısından kaynaklandığı bildirilmiştir (Coleman ve ark 2009, O'Donnell ve ark 2005). Su sistemlerindeki bu bakteri kontaminasyonunun nedenlerinden biri de, su sistemlerini oluşturan boru ağındaki uzun dönemde oluşabilen bakteri biyofilmleri olduğu gösterilmiştir (Coleman ve ark 2007, Tuttlebee ve ark 2002). Daha sonraki çalışmalar ise oluşan bu mikrobiyofilm tabakasının hangi şartlarda ortaya çıktığının ve ne gibi önlemlerle ortadan kaldırılabildiğinin araştııımasına yönelik olmuştur (Coleman ve ark 2009).

Her ne kadar su sistemlerindeki bakteriyel biyofilm, muhtemel çapraz enfeksiyonun ana kaynağı olarak gösterilse de, mikrobiyal geçişin önemli nedenlerinden biri de ağız içinde kullanılan su sistemlerindeki potansiyel geri akım olarak nitelendirilen ağız sıvılarının, kullanılan aletler aracılığıyla su sistemlerine dâhil olmasıdır (Stanley 1971). Modern diş koltuk sistemlerinin mutlaka bu geri akımı önleyici sistemlerinin bulunması gerektiği bildirilmiştir. Ancak geri akımı engelleyici sistemlerin varlığında bile geri akımdan kaynaklanan kontaminasyonların kaçınılmaz olabildiğine dair çalışmalar mevcuttur (Berlutti ve ark 2003, O'Donnell ve ark 2005, Pankhurst ve ark 1998). Ancak bu geri akım sistemlerinin güvenilirliği halen netlik kazanmamış olmakla birlikte çapraz enfeksiyon açısından ne derece riskli olduğu halen netlik kazanmamışır. Bununla birlikte yakın zamanda yapılan bir çalışmada ise modern geri akım önleyici sistemlerin zaman içinde etkinliğini yitirdiği bildirilmiştir (O'Donnell ve ark 2006).

Sonuçlarda elde edilen mikroorganizmaların birçoğu normal bireylerde basit dental girişimler sonrasında enfeksiyon oluşturma riski açısından düşük riskli olmakla beraber, bağışıklık sistemi baskılanmış hastalarda ciddi enfeksiyonlara neden olabilirler. İzole edilen bu mikroorganizmaların bazıları fırsatçı patojen olup çoğu normal hastada herhangi bir hastalığa neden olmazlar. İzole edilen bakterilerden Nonfermenter Gram(-) basiller ve pseudomonas aeruginosa gibi bakteriler yara yeri enfeksiyonundan ciddi septik tablolara kadar varan problemlere neden olabilirler. Özellikle cerrahi süresi ve invazivlik düzeyi arttıkça bu tür hastalara yapılacak girişimlerde diş hekimliği kliniklerindeki suların temiz olmasına özen gösterilmesi gerekmektedir.

Elde edilen sonuçlar gruplara göre değerlendirilecek olursa kontrol grubunda daha çok izole edilen ancak deney gruplarında daha az veya hiç izole edilmeyen bakterilerden Bacillus spp'nin birçok enfekte olmayan bölgeden izole edilebildiği hatta gıda teknolojisinde bir katkı maddesi ve probiyotik olarak kullanıldığı bilinmektedir. Ayrıca yine kontrol grubunda izole edilen deney gruplarında bulunmayan Kingella Kingae ve Brevandimonas Dimunuta gibi bakterilerin de nadir olarak enfeksiyona yol açtığı bilinmektedir. Ancak deney gruplarında elde edilen Achromobacter Spp, Delftia Acidovorans, Gram Negatif Non Fermantatif Basil gibi bakterilerin ise menejit, sepsis, pneumoni, endokardit gibi birçok enfeksiyona neden olma intimali bulunmakla beraber yukarıda da belirtildiği gibi yara enfeksiyonlarına da yol açabileceği bilinmektedir.

Sonuç olarak bu çalışmanın bulguları değerlendirildiğinde özellikle bir bölge hastanesi olarak hizmet veren ve başvuran hastaların önemli bir kısmının da immün sistemi baskılanmış, her türlü enfeksiyona yatkın, yatan hastalardan oluştuğu bir hastanede kullanılan diş ünit sistemlerinin kontaminasyonu engelleyici sistemlerle donatılmasının önemini bir kez daha ortaya koymaktadır. Bununla birlikte uzun zamandır kullanılan diş ünit sistemlerinin bu açıdan gözden geçirilmesi ve gerektiğinde yenilenmesi gerekliliği de değerlendirilmesi gereken bir konudur.

Ek olarak, su tanklarının kontaminasyonu eğer hasta kaynaklı düşünülüyorsa bulaşıcı viral hastalıklar açısından da çok dikkatli olunmalı ve bakteriyel enfeksiyonların yanında viral bulaşın çok daha ciddi problemlere yol açacağı göz ardı edilmemelidir. Bu nedenle sterilizasyon ve dezenfeksiyon kurallarına azami ölçüde riayet edilmesi su tanklarının uygun temizliği dental ve cerrahi girişimin güvenilirliği açısından dikkat edilmesi gereken önemli bir noktadır. 


\section{Diş hekimliği fakültelerinde kullanılan farklı diş ünitlerinin su ünitlerinin su sistemlerinin geri akım kontaminasyonu açısından değerlendirilmesi}

Amaç: Farklı diş koltuk sistemlerine bağlı gerikaçış engelleyici sistemlerin etkinliğinin uzun dönem araştırıması ve farklı branşlara göre gerikaçış sonucu ortaya çıkabilecek çapraz enfeksiyon riskinin belirlenmesidir.

Gereç ve Yöntemler: Dişhekimliğinin birbirinden farklı üç branşından çalışma grubu oluşturulmuştur. Bu farklı üç gruptan elde edilen materyaller bakteri varlığı açısından değerlendirilerek gruplar arasındaki farklılık mikrobiyolojik açıdan incelenmiştir.

Bulgular: Üç grupta da birçok bakteri kolonisinin izole edildiği görülmekle birlikte üreyen mikroorganizmaların çoğunun çevreden ve ağız florasından sıklıkla izole edilen bakteri kolonileri olduğu görülmüştür.

Sonuç: Diş ünit sistemlerinin kontaminasyonu engelleyici sistemlerle donatılmasının son derece önemli olduğu görülmüş, bununla birlikte uzun zamandır kullanılan diş ünit sistemlerinin sıklıkla kontrol edilmesi ve gerektiğinde yenilenmesi sonucuna ulaşılmıştır.

\section{ANAHTAR KELIMELER}

Diş ünit geri kaçış engelleyici sistem, çapraz enfeksiyon, kontaminasyon

\section{KAYNAKLAR}

Belting CM, Haberfelde GC, Juhl LK. Spread of organisms from dental air rotor, 1964. J Am Dent Assoc; 68:648-51.

Berlutti F, Testarelli L, Vaia F, Luca MD, Dolci G. Efficiacy of anti-retraction devices in preventing bacterial contamination of dental unit water lines, 2003. J Dent; 31: 100-5.

Blake GC. The incidence and control of bacterial infection of dental units and ultrasonic scalers, 1963. Br Dent J; 115:413-6.

Coleman DC, O'Donnell MJ, Shore AC, Russell RJ. Biofilm problems in dental unit water systems and its practical control, 2009. J Appl Microbiol 106:1424-37.
Coleman DC, O'Donnell MJ, Shore AC, Swan J Russell RJ. The role of manufacturers in reducing biofilms in dental chair waterlines, 2007. J Dent; 35:701-11.

Mills SE. The dental unit waterline controversy: defusing the myths, defining the solutions, 2000. J Am Dent Assoc; 131:1427-41.

Montebugloni L, Dolci G, Spratt DA, Puttaiah R. Failure of antiretraction valves and the procedure for between patient flushing: a rationale for chemical control of dental unit waterline contamination, 2005. Am J Dent; 18:270-4.

O'Donnell MJ, Tuttlebee CM, Falkiner FR, Coleman DC. Bacterial contamination of dental chair units in a modern dental hospital caused by leakage from suction system hoses containing extensive biofilm, 2005. J Hosp Infect; 59:348-60.

O'Donnell MJ, MacCarthy D, Coleman DC. Microbiology and cross-infection control. In Clinical Textbook of Dental Hygiene and Therapy, 2006. Blackwell Munksgaard Oxford, Ireland, P.181-207.

Pankhurst CL, Johnson NW, Woods RG. Microbial contamination of dental unit waterlines: the scientific argument, 1998. Int Dent J; 48:359-368.

Petti S, Tarsitani G. Detection and quantification of dental unit water line contamination by oral streptococci, 2006. Infect Control Hosp Epidemiol; 27:504-9.

Stanley HR. Pulpal response to dental techniques and materials, 1971. Dent Clin North Am; 15:115-26.

Tuttlebee CM, O'Donnell MJ, Keane CT; Russell RJ, Sullivan DJ, Falkiner F, Coleman DC. Effective control of dental chair unit waterline biofilm and marked reduction of bacterial contamination of output water using two peroxide-based disinfectants, 2002. J Hosp Infect; 52: 192-205.

Williams JF, Johnston AM, Johnson B, Huntington MK, Mackenzie CD. Microbial contamination of dental unit waterlines: prevalence, intensity and microbiological characteristic, 1993. J Am Dent Assoc; 124:59-65.

\section{Yazışma Adresi:}

Arş.Gör.Türker YÜCESOY

Erciyes Üniversitesi

Diş Hekimliği Fakültesi

Ağız, Diş ve Çene Cerrahisi AD

38039 Kayseri, Türkiye

Tel: +90 (352) 2076666 / 29189

Faks: +90 (352) 4380657

E-mail: dt.yucesoy@hotmail.com 